\title{
Pengaruh profitabilitas terhadap nilai perusahaan dengan kebijakan deviden sebagai mediasi
}

\author{
Lelly Wulan Yuni \\ Program Studi Manajemen, Fakultas Ekonomi, Universitas Islam Kadiri, Kediri, 64128, Indonesia
}

\begin{tabular}{l}
\hline INFO ARTIKEL \\
\hline Kata kunci: \\
profitabilitas; kebijakan \\
deviden; nilai \\
perusahaan; analisis \\
jalur
\end{tabular}

\begin{abstract}
ABSTRAK
Penelitian ini bertujuan untuk menganalisis pengaruh profitabilitas terhadap nilai perusahaan dengan kebijakan deviden sebagai mediasi pada PT Indofood Sukses Makmur Tbk yang terdaftar di BEl periode 2010-2019. Terdapat ketidakkonsistenan pada profitabilitas terhadap nilai perusahaan. Penelitian ini berangkat dari perbedaan hasil penelitian mengenai hubungan profitabilitas terhadap nilai perusahaan. Penelitian ini dilakukan dengan tambahan efek mediasi yang diharapkan dapat menerangkan hubungan kausal antara profitabilias dengan nilai perusahaan. Penelitian menggunakan metode kuantitatif, dengan teknik purposive sampling. Teknik analisis dengan uji asumsi klasik dan analisis jalur menggunakan aplikasi SPSS. Profitabilitas berpengaruh negatif signifikan terhadap kebijakan deviden, profitabilitas berpengaruh positif tidak signifikan terhadap nilai perusahaan, kebijakan deviden berpengaruh negatif tidak signifikan terhadap nilai perusahaan, dan kebijakan deviden tidak memediasi pengaruh profitabilitas terhadap nilai perusahaan. Perusahaan harus meningkatkan profitabilitas sehingga nilai perusahaan juga meningkat yang akan menarik calon investor. Investor lebih tertarik untuk mencapatkan capital gain dibandingkan deviden.
\end{abstract}

\begin{tabular}{l}
\hline ARTICLE INFO \\
\hline Keywords: \\
Profitability; devidend \\
policy; firm value; path \\
analysis
\end{tabular}

\begin{abstract}
This study aims to analyze the effect of profitability on firm value with dividend policy as a mediation at PT Indofood Sukses Makmur Tbk which is listed on the IDX for the 2010-2019 period. There is an inconsistency in profitability to firm value. This study departs from the differences in research results regarding the relationship between profitability and firm value. This research was conducted with additional mediating effects which are expected to explain the causal relationship between profitability and firm value. The research uses quantitative methods, with purposive sampling technique. The analysis technique uses the classical assumption test and path analysis using the SPSS application. Profitability has a significant negative effect on dividend policy, profitability does not have a significant positive effect on firm value, dividend policy does not have a significant negative effect on firm value, and dividend policy does not mediate the effect of profitability on firm value. Companies must increase profitability so that the value of the company also increases which will attract potential investors. Investors are more interested in getting capital gains than dividends.
\end{abstract}

\footnotetext{
Korespondensi Penulis: Program Studi Manajemen Fakultas Ekonomi, Universitas Islam Kadiri, Jalan Sersan Suharmadji No. 38, Manisrenggo, Kediri 64128, Indonesia. E-mail: lellywulan2@gmail.com
} 


\section{Pendahuluan}

Setiap perusahaan perlu mencapai tingkat laba semaksimal mungkin. Dimana kelangsungan usaha hidup maupun perkembangan perusahaan dimasa yang akan datang menjadi lebih terjamin dengan adanya pencapaian tingkat laba tersebut. Perusahaan harus mampu mengelola keuangannya dengan baik, artinya kebijakan pengelola keuangan harus dapat menjamin keberlangsungan usaha perusahaan.

Tujuan didirikannya perusahaan adalah memenuhi kebutuhan manusia akan produk dan mempertahankan eksistensi perusahaan, dengan cara meningkatkan seluruh aktivitas perusahaan dan mengoptimalkan yang diperoleh melalui peningkatan penjualan produk dan meminimalkan biaya operasional. Hal tersebut dapat diukur dengan menggunakan rasio profitabilitas.

Menurut Kasmir (2016), profitabilitas digunakan untuk menilai kemampuan perusahaan dalam mencari keuntungan. Dan juga memberikan ukuran tingkat efektivitas manajemen suatu perusahaan. Hal ini ditunjukkan oleh laba yang dihasilkan dari penjualan dan pendapatan investasi. Intinya bahwa profitabilitas menunjukkan efisiensi perusahaan. Profitabilitas merupakan kemampuan perusahaan untuk menghasilkan laba.

Susilawati dalam Dewanti (2018) juga menjelaskan bahwa profitabilitas menggambarkan kemampuan perusahaan mendapatkan laba melalui semua kemampuan dan sumber daya yang ada seperti kegiatan penjualan, kas, modal, jumlah karyawan, jumlah cabang, dan lain sebagainya. Tingginya profitabilitas perusahaan dapat mempengaruhi nilai perusahaan dan itu tergantung dari bagaimana persepsi investor terhadap peningkatan profitabilitas perusahaan. Profitabilitas merupakan indikator yang sering digunakan investor untuk melihat nilai dari sebuah perusahaan.

Profitabilitas merupakan daya tarik utama bagi pemilik perusahaan (pemegang saham) karena profitabilitas adalah hasil yang diperoleh melalui usaha manajemen atas dana yang di investasikan oleh para pemegang saham dan profitabilitas juga mencerminkan pembagian laba yang menjadi haknya yaitu seberapa banyak dana yang diinvestasikan kembali dan seberapa banyak yang dibayarkan sebagai dividen tunai ataupun dividen saham kepada para pemilik saham (Jusriaini dan Rahardjo, 2013).

Kebijakan dividen merupakan keputusan yang sangat penting dalam perusahaan. Kebijakan ini akan melibatkan dua pihak yang memiliki kepentingan yang berbeda yaitu pihak pertama, para pemegang saham dan pihak kedua, manajemen perusahaan itu sendiri. Manajemen perusahaan memiliki dua alternatif perlakuan terhadap laba bersih setelah pajak atau EAT (Earnings After Tax). Dua alternatif tersebut yaitu dibagi kepada para pemegang saham dalam bentuk dividen dan diinvestasikan 
kembali ke perusahaan sebagai laba ditahan. Dalam perusahaan pada umumnya, sebagian EAT dibagikan dalam bentuk dividen dan sebagian lagi diinvestasikan kembali, artinya manajemen harus membuat suatu kebijakan dividen menyangkut penggunaan laba yang menjadi hak para pemegang saham dengan menentukan beasarnya EAT yang dibagi sebagai dividen dan besarnya EAT yang ditahan (Ratih, 2010).

Rudianto (2009), menyatakan dividen adalah bagian dari laba yang diperoleh perusahaan dan diberikan oleh perusahaan kepada pemegang saham sebagai imbalan atas kesediaannya menanamkan hartanya didalam perusahaan, sedangkan menurut Mehrani et al. dalam Dewanti (2018) selain dapat meningkatkan kesejahteraan pemilik perusahaan, pembayaran dividen berpengaruh terhadap nilai perusahaan, oleh karena itu memiliki posisi yang spesial bagi para pemegang saham. Besarnya dividen yang dibagikan oleh perusahaan dapat mempengaruhi harga saham karena investor lebih menyukai pengembalian yang berasal dari dividen dibandingkan dengan capital gain atau dengan kata lain investor lebih menyukai keuntungan dalam bentuk dividen dari pada keuntungan yang diharapkan dari kenaikan nilai modal.

Teori bird in the hand menyatakan bahwa pemegang saham lebih menyukai dividen yang tinggi karena memiliki kepastian yang tinggi dibandingkan capital gain (Hermuningsih \& Wardani, 2009). Pada aktivitas pasar modal, para investor memiliki harapan dari investasi yang dilakukannya, yaitu berupa capital gain dan dividen. Bagi para pemegang saham yang tidak menyukai risiko akan lebih memilih menerima dividen daripada capital gain. Dividen yang ada saat ini mempunyai nilai yang lebih tinggi daripada capital gain yang akan diterima di masa yang akan datang. Hal ini sesuai yang diungkapkan oleh Lintner (1962) yaitu The bird in the hand theory. Dengan demikian pemegang saham yang takut resiko akan lebih baik menyukai menerima dividen daripada capital gain.

Menurut Sartono (2001), kebijakan dividen ini terkait dengan keputusan apakah laba yang diperoleh perusahaan akan dibagikan kepada pemegang saham sebagai dividen atau ditahan dalam bentuk laba ditahan guna pembiayaan investasi dimasa datang. Pembagian dividen akan membuat pemegang saham mempunyai tambahan return selain dari capital gain.

Kebijakan dividen diukur dengan Dividend Payout Ratio (DPR). Sebaliknya jika perusahaan memilih untuk menahan laba yang diperoleh, maka kemampuan pembentukan dana intern akan semakin besar. Persaingan usaha yang semakin meningkat dan semakin rumit situasi yang dihadapi oleh perusahaan masa kini dan peran seorang manajer keuangan yang semakin luas. Perusahaan melalui manajer keuangan harus mampu menjalankan fungsinya di dalam mengelola keuangan dengan benar dan seefisien 
mungkin. Ukuran yang digunakan untuk menilai keberhasilan seorang manajer keuangan dalam mengelola keuangan perusahaan adalah dengan melihat nilai perusahaan.

Nilai perusahaan merupakan harga yang bersedia dibayar oleh calon pembeli apabila perusahaan dijual. Semakin tinggi nilai perusahaan, semakin besar kemakmuran yang akan diterima oleh pemilik perusahaan (Wiagustini, 2010). Nilai yang mencerminkan berapa harga yang bersedia dibayar oleh investor untuk suatu perusahaan. Harga saham yang tinggi membuat nilai perusahaan juga tinggi. Memaksimalkan nilai perusahaan sangat penting artinya bagi suatu perusahaan, karena dengan memaksimalkan nilai perusahaan berarti juga memaksimalkan kemakmuran pemegang saham yang merupakan tujuan utama perusahaan.

Nilai perusahaan sangat penting karena mencerminkan kinerja perusahaan yang dapat mempengaruhi persepsi investor terhadap perusahaan. Nilai perusahaan merupakan persepsi investor terhadap tingkat keberhasilan perusahaan yang dikaitkan dengan harga saham. Harga saham yang tinggi membuat nilai perusahaan juga tinggi. Nilai perusahaan yang tinggi akan membuat pasar percaya tidak hanya pada kinerja perusahaan saat ini namun pada prospek perusahaan di masa depan. Nilai perusahaan pada umumnya ditunjukkan dari nilai price to book value (PBV).

Menurut Brigham \& Houston (2006), PBV adalah perbandingan antara harga saham dengan nilai buku perusahaan. Dimana nilai buku perusahaan (book value share) adalah perbandingan antara ekuitas saham biasa dengan jumlah saham yang beredar.

Penelitian ini bertujuan untuk menganalisis pengaruh Profitabilitas terhadap Nilai Perusahaan dengan Kebijakan Deviden sebagai Variabel Mediasi pada PT Indofood Sukses Makmur Tbk yang terdaftar di BEI periode 2010-2019.

\section{Tinjauan Pustaka dan Pengembangan Hipotesis}

\subsection{Profitabilitas}

Menurut Sartono (2001), profitabilitas adalah kemampuan perusahaan memperoleh laba dalam hubungannya dengan penjualan, total aktiva maupun modal sendiri. Menurut Fahmi (2013) adalah profitabilitas untuk menunjukan keberhasilan perusahaan didalam menghasilkan keuntungan. Para investor melihat profitabilitas perusahaan karena profitabilitas merupakan salah satu indikator yang paling baik mengenai kesehatan keuangan perusahaan.

Masalah profitabilitas merupakan hal yang penting di samping masalah laba, karena laba yang besar belum merupakan suatu ukuran bahwa suatu perusahaan telah bekerja secara efisien. Efisien baru dapat diketahui dengan membandingkan laba yang digunakan untuk menghasilkan laba tersebut, atau dengan kata lain adalah menghitung profitabilitas.

Investor yang potensial akan menganalisis dengan cermat kelancaran sebuah perusahaan 
dan kemampuannya untuk mendapatkan keuntungan. Semakin baik rasio profitabilitas maka menggambarkan semakin baik kemampuan perolehan keuntungan perusahaan. Dari permasalahan ini menyangkut efektifitas manajemen dalam menggunakan total aktiva maupun aktiva bersih seperti yang tercatat dalam neraca. Efektifitas dinilai dengan menghubungkan laba bersih terhadap aktiva yang digunakan untuk menghasilkan laba.

Penilaian profitabilitas dalam penelitian ini menggunakan return on equity (ROE), karena ROE menunjukkan kemampuan atas modal yang diinvestasikan dalam keseluruhan aktiva yang dimiliki untuk menghasilkan laba. Rasio ROE ini sering dipakai manajemen untuk mengukur kinerja keuangan perusahaan dan menilai kinerja operasional dalam memanfaatkan sumber daya yang dimiliki perusahaan.

$$
\text { ROE }=\frac{\text { Laba bersih }}{\text { Ekuitas }}
$$

\subsection{Kebijakan Deviden}

Setiap perusahaan memiliki dua perlakuan alternatif terhadap laba bersih sesudah pajak yakni dibagikan kepada para pemegang saham berupa dividen atau diinvestasikan kembali ke perusahaan dalam bentuk laba ditahan. Dalam membagikan laba bersih setelah pajak, perusahaan harus memiliki keputusan mengenai besarnya laba bersih setelah pajak yang dibagikan perusahaan dalam bentuk dividen.
Keputusan inilah yang disebut sebagai kebijakan dividen (Atmaja, 2003).

Menurut Sartono (2001), kebijakan dividen adalah kebijakan yang dimiliki perusahaan untuk membagikan labanya kepada para pemegang saham. Menurut Brigham \& Houston (2006), suatu perusahan harus mencapai keseimbangan diantara dividen saat ini dan pertumbuhan dimasa depan sehingga dapat memaksimalkan harga saham.

Pengertian rasio pembayaran dividen (dividend payout ratio) menurut Sartono (2001) menyatakan bahwa rasio pembayaran dividen adalah persentase laba yang dibayarkan dalam bentuk dividen, atau rasio antara laba yang dibayarkan dalam bentuk dividen dengan total laba yang tersedia bagi pemegang saham. Sedangkan menurut Sutrisno (2009), Dividend Payout Ratio adalah prosentase laba yang dibagikan sebagai dividen, dimana semakin besar Dividend Payout Ratio semakin kecil porsi dana yang tersedia untuk ditanamkan kembali ke perusahaan sebagai laba ditahan.

Menurut Zaki Baridwan (2004) secara matematis Dividend Payout Ratio dapat dirumuskan sebagai berikut:

Dividend Payout Ratio $=\frac{\text { deviden per share }}{\text { earning per share }} \times 100 \%$

\subsection{Nilai Perusahaan}

Menurut Sartono (2001), nilai perusahaan adalah persepsi investor terhadap tingkat keberhasilan perusahaan yang sering dikaitkan 
dengan harga saham. Pengukuran nilai perusahaan dalam penelitian ini diproksikan pada Price Book Value (PBV). PBV merupakan salah satu rasio keuangan yang cukup untuk melihat perusahaan dalam menciptakan nilai. Rasio PBV menggunakan hasil pembagian harga per lembar saham penutupan (closing price) akhir tahun dengan nilai buku perlembar saham (total ekuitas dibagi dengan jumlah saham beredar pada akhir tahun). Semakin tinggi PBV tersebut semakin berhasil perusahaan menciptakan nilai bagi pemegang saham.

$$
\mathrm{PBV}=\frac{\text { Harga pasar per saham }}{\text { Nilai Buku }}
$$

\subsection{Profitabilitas dan Kebijakan Deviden}

Tujuan investor menanamkan modalnya berupa saham pada perusahaan-perusahaan terbuka yakni untuk mendapatkan dividen. Semakin tinggi profitabilitas maka semakin besar juga deviden yang akan di bagikan kepada pemegang saham sehingga meningkatkan nilai aliran kas yang didapatkan perusahaan maka kesempatan perusahaan untuk membayar dividen juga semakin tinggi.

Hasil penelitian Wijaya \& Sedana (2015) menemukan bukti bahwa profitabilitas memiliki pengaruh positif dan signifikan terhadap kebijakan dividen. Menurut Alamsyah (2017) menemukan bukti bahwa profiabilitas memiliki pengaruh positif dan signifikan terhadap kebijakan deviden. Dilihat dari investor menanamkan berupa saham pada perusahaan- perusahaan terbuka yakni mendapatkan deviden. Semakin tinggi aliran kas yang di dapatkan perusahaan maka kesempatan perusahaan untuk membayar deviden juga semakin tinggi.

H1. Profitabilitas berpengaruh positif terhadap kebijakan deviden.

\subsection{Profitabilitas dan Nilai Perusahaan}

Menurut Wijaya \& Sedana (2015), menyatakan bahwa kemampuan perusahaan menghasilkan laba menjadi salah satu indikator yang penting bagi para investor untuk mengetahui seberapa besar kemampuan perusahaan dalam menghasilkan laba. Perusahaan yang mengalami peningkatan laba mencerminkan bahwa perusahaan memiliki kinerja yang baik sehingga dapat menimbulkan citra yang positif dimata investor yang menyebabkan harga saham dalam perusahaan mengalami peningkatan. Meningkatnya laba yang dihasilkan perusahaan berarti meningkat pula nilai perusahaan di pasar.

Lifessy (2011), menyatakan bahwa dengan tingginya laba yang dihasilkan, berarti prospek perusahaan untuk menjalankan operasinya dimasa depan juga tinggi sehingga nilai perusahaan yang tercermin dari harga saham perusahaan akan meningkat pula. Perusahaan yang mengalami peningkatan laba mencerminkan bahwa perusahaan memiliki kinerja yang baik sehingga dapat menimbulkan citra yang positif dimata investor yang juga 
menyebabkan harga saham dalam perusahaan mengalami peningkatan. Hasil penelitian yang dilakukan oleh Wijaya \& Sedana (2015), menemukan bukti bahwa profitabilitas berpengaruh positif dan signifikan terhadap nilai perusahan.

H2. Profitabilitas berpengaruh positif terhadap nilai perusahaan.

\subsection{Kebijakan Deviden dan Nilai Perusahaan}

Nilai perusahaan dapat dilihat dari kemampuan perusahaan membayar dividen. Kemampuan membayar dividen sangat berkaitan dengan kemampuan perusahaan dalam menghasilkan laba. Perusahaan yang dapat meningkatkan labanya akan mendapatkan sinyal positif oleh investor, dimana respon positif ini akan meningkatkan nilai perusahaan karena tujuan investor menanamkan modalnya yakni memperoleh dividen.

Penelitian yang dilakukan oleh Agung Gede et al (2018:3792) menemukan bukti bahwa kebijakan dividen berpengaruh positif dan signifikan terhadap nilai perusahaan. Wijaya \& Sedana (2015) menemukan bukti bahwa kebijakan dividen berpengaruh positif dan signifikan terhadap nilai perusahaan. Nilai perusahaan dapat dilihat dari kemampuan perusahaan membayar dividen.

H3. Kebijakan deviden berpengaruh positif terhadap nilai perusahaan.

H4. Kebijakan deviden memediasi profitabilitas terhadap nilai perusahaan.

\subsection{Kerangka konseptual}

Berdasarkan pembentukan hipotesis, kami menggambarkan kerangka teoritis integratif pada gambar 1 .

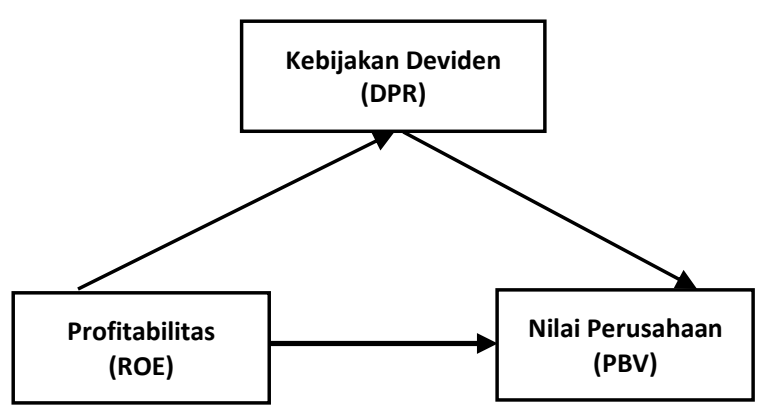

Gambar 1. Model Penelitian

\section{Metodologi}

\subsection{Jenis Penelitian}

Penelitian menggunakan jenis penelitian kuantitatif asosiatif. Menurut Sujarweni (2015), penelitian asosiatif merupakan penelitian yang bertujuan untuk mengetahui hubungan antara dua variabel atau lebih.

\subsection{Populasi dan Sampel}

Teknik yang digunakan untuk pengambilan sampel dalam penelitian ini adalah teknik purposive sampling. Menurut Sugiyono (2015), teknik purposive sampling adalah teknik pengambilan sampel secara sengaja dalam dipilih atas kriteria tertentu. Kriteria tersebut yaitu: 1 ). Seluruh laporan keuangan perusahaan PT. Indofood Sukses Makmur Tbk. yang terdaftar di bursa efek Indonesia (BEI) periode 2010-2019; 2). Perusahaan PT Indofood Sukses Makmur Tbk yang terdaftar di BEI mengeluarkan laporan keuangan di tahun 2010-2019 seacara berturutturut. 


\subsection{Teknik Analisis}

\section{Uji Asumsi Klasik}

Uji asumsi klasik merupakan salah satu pengujian prasyarat pada regresi linier berganda. Suatu data yang valid harus memenuhi kriteria BLUE (Best, Liniear, Unbiased, and Estimated). yang digunakan yaitu: uji normalitas, multikolinearitas, heteroskedastisitas dan autokorelasi.

\section{Uji Analisis Jalur}

Menurut Sarwono (2014), path analysis merupakan teknik yang digunakan untuk menganalisis hubungan sebab akibat yang inheren antara variabel yang disusun menggunakan koefisien jalur sebagai besaran nilai dalam menentukan besarnya pengaruh variabel independen (exogenous) terhadap variabel dependen (endogenous).

Hubungan langsung terjadi jika satu variabel mempengaruhi variabel lainnya tanpa ada variabel ketiga yang memediasi. Hubungan tidak langsung terjadi jika ada variabel ketiga yang memediasi hubungan kedua variabel ini (Ghozali, 2018).

Pengaruh langsung ROE ke DPR $=p 1$

Pengaruh tidak langsung antara ROE ke PBV ke $D P R=p 2 \times p 3$

Menurut Hamidy (2015), apabila perbandingan didapatkan hasil bahwa pengaruh tidak langsung lebih tinggi daripada pengaruh langsung, maka dapat dinyatakan bahwa variabel $Z$ dapat berfungsi sebagai variabel mediasi.

\section{Uji Koefisien Determinasi}

Koefisien determinasi merupakan kuadrat dari koefisien korelasi sedangkan untuk mengetahui kemampuan masing-masing variabel yang digunakan. Koefisien determinasi $\left(R^{2}\right)$ mengukur seberapa jauh kemampuan model dalam menerangkan variasi variabel dependen. Nilai koefisien determinasi adalah antara nol dan satu. Nilai $\left(R^{2}\right)$ yang kecil berarti kemampuan variabel-variabel independen dalam menjelaskan variasi variabel dependen sangat terbatas. Nilai yang mendekati satu berarti variabel-variabel independen memberikan hampir semua informasi yang dibutuhkan untuk memprediksi variasi variabel dependen (Ghozali, 2011).

\section{Hasil}

\subsection{Hasil Uji Asumsi Klasik}

Tabel 1. Uji Normalitas

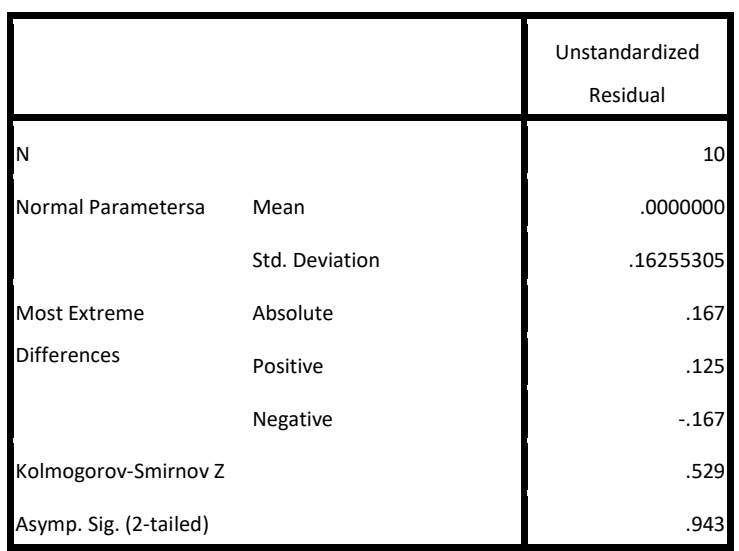

Berdasarkan hasil uji normalitas di atas telah diketahui nilai dari test statistic kolmogorov-smirnov sebesar 0,529 dan nilai Asymp. Sig. (2-tailed) sebesar 0,943, artinya adalah nilai tersebut lebih besar dari nilai profitabilitas 0,05. Jadi dapat disimpulkan bahwa 
data dalam penelitian ini berdistribusi normal dan peneliti dapat melanjutkan ke tahap uji berikutnya.

Tabel 2. Uji Multikolinearitas

\begin{tabular}{|c|c|c|c|c|c|c|c|}
\hline \multirow[b]{2}{*}{ Model } & \multicolumn{2}{|c|}{$\begin{array}{l}\text { Unstandardized } \\
\text { Coefficients }\end{array}$} & \multirow{2}{*}{$\begin{array}{c}\begin{array}{c}\text { Standardized } \\
\text { Coefficients }\end{array} \\
\text { Beta }\end{array}$} & \multirow[b]{2}{*}{$\mathrm{t}$} & \multirow[b]{2}{*}{ Sig. } & \multicolumn{2}{|c|}{$\begin{array}{l}\text { Collinearity } \\
\text { Statistics }\end{array}$} \\
\hline & B & $\begin{array}{l}\text { Std. } \\
\text { Error }\end{array}$ & & & & $\begin{array}{c}\text { Toleranc } \\
\mathrm{e}\end{array}$ & VIF \\
\hline 1 (Constant) & 1.111 & .989 & & 1.124 & .298 & & \\
\hline ROE & 2.965 & 5.603 & .403 & .529 & .613 & .182 & 5.481 \\
\hline DPR & -.001 & .008 & -114. & -.150 & .885 & .182 & 5.481 \\
\hline
\end{tabular}

Berdasarkan hasil uji multikolinearitas tabel 2 didapatkan nilai dari tolerance yaitu sebesar 0,182, dimana nilai ini lebih besar dari 0,1 . Dan didapatkan nilai dari VIF sebesar 5,481, dimana nilai ini lebih kecil dari 10. Jadi dapat disimpulkan analisis model regresi pada penelitian ini tidak terdapat gejala multikolinearitas dan data penelitian ini layak untuk digunakan.

Statterpist

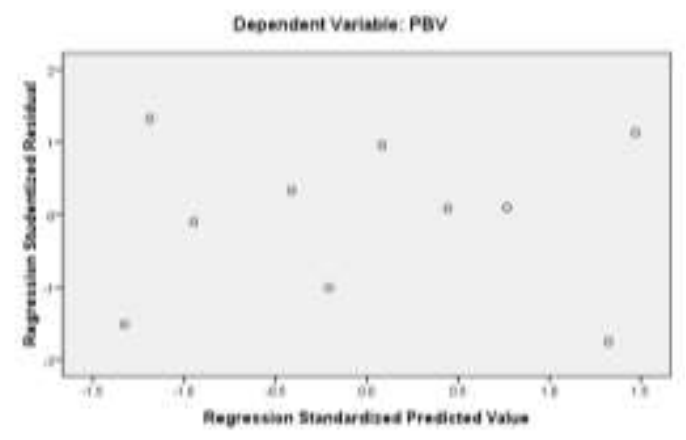

Gambar 2. Uji Heteroskedastisitas

Untuk mendeteksi adanya heteroskedastitas dapat dilakukan dengan melihat garis scatterplots antar nilai prediksi variabel terikat dengan residualnya.
Heteroskedastitas tidak terjadi dalam suatu model jika titik dalam grafik scatterplots menyebar secara acak dan tersebar baik di atas maupun di bawah angka 0 pada sumbu $Y$.

Tabel 3. Uji Autokorelasi

\begin{tabular}{|l|r|r|r|r|r|}
\hline $\begin{array}{l}\text { Mod } \\
\mathrm{el}\end{array}$ & $\mathrm{R}$ & $\begin{array}{c}\mathrm{R} \\
\text { Square }\end{array}$ & $\begin{array}{c}\text { Adjusted R } \\
\text { Square }\end{array}$ & $\begin{array}{c}\text { Std. Error } \\
\text { of the } \\
\text { Estimate }\end{array}$ & $\begin{array}{l}\text { Durbin- } \\
\text { Watson }\end{array}$ \\
\hline 1 & .509 & .259 & .047 & .18432 & 2.444 \\
\hline
\end{tabular}

Berdasarkan hasil dari tabel uji autokorelasi, diketahui nilai dari durbin watson sebesar 2,444. Nilai dL yang dilihat dari tabel durbin watson diketahui sebesar 0,6972, dan nilai dari dU diketahui sebesar 1,6413. Maka dapat disimpulkan model regresi dalam penelitian ini tidak dapat disimpulkan karena 4$\mathrm{dU}<\mathrm{DW}<4$-dL atau 2,3587 <2,444<3,3028.

\subsection{Hasil Uji Analisis Jalur}

Tabel 4. Analisis Regresi Model 1

\begin{tabular}{|c|c|c|c|c|c|c|}
\hline & \multirow{2}{*}{ Model } & \multicolumn{2}{|c|}{$\begin{array}{l}\text { Unstandardized } \\
\text { Coefficients }\end{array}$} & \multirow{2}{*}{$\begin{array}{c}\begin{array}{c}\text { Standardized } \\
\text { Coefficients }\end{array} \\
\text { Beta } \\
\end{array}$} & \multirow[b]{2}{*}{$\mathrm{T}$} & \multirow[b]{2}{*}{ Sig. } \\
\hline & & B & Std. Error & & & \\
\hline \multirow[t]{2}{*}{1} & (Constant) & 121.431 & 13.275 & & 9.147 & .000 \\
\hline & Profitabilitas & -651.146 & 108.749 & -.904 & -5.988 & .000 \\
\hline
\end{tabular}

Dari tabel 4. dapat diketahui bahwa pada variabel Profitabilitas mempunyai nilai signifikansi sebesar 0,000. Nilai sig ini lebih kecil dari taraf signifikansi 0,05, sehingga regresi jalur model 1 dapat disimpulkan bahwa terdapat pengaruh signifikan antara variabel Profitabilitas (X) terhadap Kebijakan Deviden (Z). 
Tabel 5. Analisis Regresi Model 2

\begin{tabular}{|c|c|c|c|c|c|}
\hline \multirow[b]{2}{*}{ Model } & \multicolumn{2}{|c|}{$\begin{array}{l}\text { Unstandardized } \\
\text { Coefficients }\end{array}$} & $\begin{array}{c}\text { Standardized } \\
\text { Coefficients }\end{array}$ & \multirow[b]{2}{*}{$\mathrm{t}$} & \multirow[b]{2}{*}{ Sig. } \\
\hline & B & Std. Error & Beta & & \\
\hline $1 \quad$ (Constant) & 1.111 & 989 & & $\begin{array}{r}1.12 \\
4\end{array}$ & 298 \\
\hline Profitabilitas & 2.965 & 5.603 & .403 & .529 & .613 \\
\hline $\begin{array}{l}\text { Kebijakan } \\
\text { Dividen }\end{array}$ & -.001 & .008 & -114 & -.150 & .885 \\
\hline
\end{tabular}

Dari tabel 5. diketahui bahwa pada variabel Profitabilitas menghasilkan nilai signifikansi sebesar 0,613 , nilai profitabilitas ini lebih besar dari taraf signifikan 0,05. Maka HO diterima $\mathrm{H} 1$ ditolak yang artinya profitabilitas mempunyai pengaruh yang tidak signifikan terhadap kebijakan deviden. Dan pada variabel DPR menghasilkan nilai signifikansi sebesar 0,885, nilai sig ini lebih besar dari nilai probabilitas 0,05 , sehingga regresi jalur model 2 dapat disimpulkan bahwa tidak terdapat pengaruh signifikan antara variabel ROE $(X)$ dan DPR (Z) terhadap nilai perusahaan (Y).

Pengaruh langsung dan pengaruh tidak langsung

Persamaan analisis jalur dapat dituliskan sebagai berikut:

$Z=121,431-651,146 X$

$Y=1,111+2,965 X-0,001 Z$

$Z-Y=(-651,146) \times(-0,001)=0,651$

Berdasarkan hasil yang diperoleh, diketahui nilai pengaruh langsung yaitu sebesar 2,965 dan pengaruh tidak langsung sebesar 0,651, dimana nilai pengaruh langsung lebih besar dari nilai pengaruh tidak langsung. Maka dapat disimpulkan variabel kebijakan dividen (Z) tidak dapat dikatakan sebagai variabel intervening atau dengan kata lain kebijakan dividen tidak memediasi variabel profitabilitas $(\mathrm{X})$ terhadap nilai perusahaan $(\mathrm{Y})$.

\subsection{Hasil Uji Koefisien Determinasi}

\section{Model 1}

Tabel 6. Koefisien Determinasi Model 1

\begin{tabular}{|l|r|r|r|r|}
\hline Model & \multicolumn{1}{|c|}{$\mathrm{R}$} & $\mathrm{R}$ Square & \multicolumn{1}{c|}{$\begin{array}{c}\text { Adjusted R } \\
\text { Square }\end{array}$} & $\begin{array}{c}\text { Std. Error of } \\
\text { the Estimate }\end{array}$ \\
\hline 1 & $.904^{\mathrm{a}}$ & .818 & .795 & 8.37533 \\
\hline
\end{tabular}

Berdasarkan hasil koefisien determinasi model 1 pada tabel 6 di bawah dapat diketahui bahwa nilai $R$ Square sebesar 0,818 artinya adalah menunjukkan koefisien determinasinya. Dengan kata lain variasi dalam variabel kebijakan dividen (Z) dapat dijelaskan oleh variabel profitabilitas $(X)$ melalui model regresi sebesar $81,8 \%$, sisanya $18,2 \%$ berasal dari variabel lain diluar dari penelitian.

\section{Model 2}

Tabel 7. Koefisien Determinasi Model 2

\begin{tabular}{|l|r|r|r|r|}
\hline Model & \multicolumn{1}{|c|}{$\mathrm{R}$} & $\mathrm{R}$ Square & \multicolumn{1}{c|}{$\begin{array}{c}\text { Adjusted R } \\
\text { Square }\end{array}$} & $\begin{array}{c}\text { Std. Error of } \\
\text { the Estimate }\end{array}$ \\
\hline 1 & $.509^{\mathrm{a}}$ & .259 & .047 & .18432 \\
\hline
\end{tabular}

Berdasarkan hasil koefisien determinasi jalur model 2 pada tabel diatas dapat diketahui bahwa nilai $R$ Square sebesar 0,259 artinya adalah menunjukkan koefisien determinasinya. Dengan kata lain variasi dalam variabel nilai perusahaan $(\mathrm{Y})$ dapat dijelaskan oleh variabel profitabilitas (X) dan kebijakan dividen (Z) melalui 
model regresi sebesar $25,9 \%$, sisanya $74,1 \%$ berasal dari variabel lain diluar dari penelitian.

\section{Pembahasan}

\subsection{Profitabilitas terhadap kebijakan deviden}

Hasil dari uji hipotesis dapat disimpulkan bahwa hasil hipotesis pertama yaitu diperoleh nilai koefisien regresi jalur path sebesar -651,146 dan nilai profitabilitasnya sebesar 0,000 , nilai profitabilitas ini lebih kecil dari taraf signifikansi 0,05. Maka disini HO ditolak dan $\mathrm{H} 1$ diterima yang artinya nilai dari koefisien regresi dan nilai signifikansi ini dapat menunjukkan bahwa variabel $X$ yaitu profitabilitas mempunyai pengaruh negatif dan signifikan terhadap kebijakan dividen pada PT. Indofood Sukses Makmur. Dapat disimpulkan bahwa semakin turun profitabilitas maka semakin naik kebijakan devidennya. Perusahaan ingin mempertahankan investor agar tetap menanamkan saham, karena investor berperan sangat penting dalam modal perusahaan. Terdapat dilihat pada tahun 2013 perusahaan memiliki profitabilitas yang menurun tetapi deviden kas yang di bagikan ke investor naik.

\subsection{Profitabilitas terhadap nilai perusahaan}

Hasil dari uji hipotesis dapat disimpulkan bahwa hasil hipotesis kedua yaitu diperoleh nilai koefisien regresi jalur path sebesar 2,965 dan nilai profitabilitasnya sebesar 0,613 , nilai profitabilitas ini lebih besar dari taraf signifikansi 0,05. Maka disini $\mathrm{HO}$ diterima dan $\mathrm{H} 1$ ditolak yang artinya nilai dari koefisien regresi dan nilai signifikansi ini dapat menunjukkan bahwa variabel $X$ yaitu profitabilitas (ROE) berpengaruh positif tidak signifikan terhadap nilai perusahaan (PBV) pada PT. Indofood Sukses Makmur. Dapat disimpulkan bahwa semakin tinggi nilai dari profitabilitas maka semakin tinggi nilai perusahaan yang akan diperoleh, namun peningkatan profitabilitas bukan sebuah faktor utama yang membuat nilai perusahaan menjadi tinggi.

\subsection{Kebijakan deviden terhadap nilai perusahaan}

Hasil dari uji hipotesis dapat disimpulkan bahwa hasil hipotesis ketiga yaitu diperoleh nilai koefisien regresi jalur path sebesar $-0,001$ dan nilai profitabilitasnya sebesar 0,885 , nilai profitabilitas ini lebih besar dari taraf signifikansi 0,05. Maka disini $\mathrm{HO}$ diterima dan $\mathrm{H} 1$ ditolak yang artinya nilai dari koefisien regresi dan nilai signifikansi ini dapat menunjukkan bahwa variabel $Z$ yaitu kebijakan dividen (DPR) berpengaruh negatif tidak signifikan terhadap nilai perusahaan (PBV) pada PT. Indofood Sukses Makmur. Dapat disimpulkan bahwa semakin turun nilai dari kebijakan dividen maka semakin turun nilai perusahaan. Besar kecilnya deviden yang akan dibagikan oleh perusahaan akan berpengaruh pada harga saham. Perusahaan yang memberikan devidennya secara tidak konsisten dan terus menurun akan memberikan citra negatif dimata para investor. Menurunnya harga saham perusahaan akan berpengaruh pada menurunya nilai suatu perusahaan. 


\subsection{Kebijakan deviden memediasi profitabilitas} terhadap nilai perusahaan

Hasil dari uji hipotesis dapat disimpulkan bahwa hasil hipotesis keempat yaitu diperoleh nilai pengaruh langsung yaitu sebesar 2,965 dan pengaruh tidak langsung sebesar 0,651, dimana nilai pengaruh langsung lebih besar dari nilai pengaruh tidak langsung. Maka dapat disimpulkan variabel kebijakan dividen (Z) tidak dapat dikatakan sebagai variabel intervening atau dengan kata lain kebijakan dividen tidak memediasi variabel profitabilitas $(X)$ terhadap nilai perusahaan (Y). Bagi investor pendapatan relevan adalah pendapatan setelah pajak baik deviden maupun capital gain. Dan apabila capital gain dikenakan tarif pajak lebih rendah di bandingkan pajak deviden, maka investor lebih tertarik untuk mendapatkan capital gain.

Hal ini disebabkan beberapa faktor, pertama investor yang menerima deviden akan lebih memilih menanamkan kembali labanya dengan harga saham akan meningkat sehingga capital gain dengan pajak rendah dan menggantikan deviden yang pajaknya tinggi. Kedua, pajak atas capital gain tidak akan dibayarkan sampai saham tersebut dijual sehingga dapat menunda pembayaran pajak, selain itu seorang yang ahli waris juga tidak dikenakan pajak atas capital gain tersebut.

\section{Kesimpulan dan Saran}

Profitabilitas memiliki pengaruh negatif dan signifikan terhadap kebijakan deviden.
Profitabilitas memiliki pengaruh positif dan tidak signifikan terhadap nilai perusahaan. Kebijakan Deviden memiliki pengaruh negatif dan tidak signifikan terhadap nilai perusahaan. Kebijakan deviden tidak memediasi pengaruh antara profitabilitas terhadap nilai perusahaan.

Perusahaan hendaknya meningkatkan kinerja perusahaan tiap tahunnya agar menghasilkan profitabilitas yang optimal sehingga nilai perusahaan akan semakin meningkat di dalam pemegang saham. Penelitian selanjutnya, diharapkan agar menambah variabel lain sebagai variabel intervening atau menggunakan proksi lain dan dapat dikembangkan dengan memperluas model penelitian sebelumnya. Menggunakan alat penelitian yang lebih baik sehingga mendapatkan hasil dan kesimpulan yang lebih akurat dan lebih valid.

\section{Daftar Pustaka}

Alamsyah, S. (2017). Pengaruh Profitabilitas Terhadap Nilai Perusahaan, Relevansi Nilai Informasi Akuntansi, Keputusan Investasi, Kebijakan Dividen Sebagai Variabel Intervening (Studi Empiris Pada Perusahaan Indeks Kompas 100 Periode 2010-2013). Competitive Jurnal Akuntansi Dan Keuangan, 1(1), 136-161.

Atmaja, L. S. (2003). Manajemen Keuangan edisi revisi. Yogyakarta: Penerbit Andi.

Brigham, E. F., \& Houston, J. F. (2006). Dasardasar manajemen keuangan, edisi 11. 
Jakarta: Salemba Empat.

Dewanti, D. R. (2018). Analisis Pengaruh Profitabilitas, Leverage, Ukuran Perusahaan, Dan Komite Audit Terhadap Audit Delay Pada Sektor Perbankan Yang Terdaftar Di Bursa Efek Indonesia (BEI) Periode 2011-2016. STIE Indonesia Banking School.

Fahmi, I. (2013). Analisis Laporan Keuangan. Bandung: Alfabeta.

Ghozali, I. (2018). Aplikasi analisis multivariate dengan program IBM SPSS 25. Semarang: Badan Penerbit Undip.

Hermuningsih, S., \& Wardani, D. K. (2009). Faktor-faktor yang mempengaruhi nilai perusahaan pada perusahaan yang terdaftar di Bursa Efek Malaysia dan Bursa Efek Indonesia. Jurnal Siasat Bisnis, 13(2), 173-183.

Kasmir. (2016). Pengantar Manajemen Keuangan: Edisi Kedua. In Jakarta: Prenada Media Group.

Lintner, J. (1962). Dividends, earnings, leverage, stock prices and the supply of capital to corporations. The Review of Economics and Statistics, 243-269.

Sartono, A. (2001). Manajemen keuangan teori dan aplikasi. Yogyakarta: BPFE.

Sarwono, J. (2014). Path analysis dengan SPSS. Elex Media Komputindo.

Sugiyono. (2015). Metode Penelitian Pendidikan:
Pendekatan Kuantitatif, Kualitatif, dan $R \& D$. Alfabeta.

Sujarweni, V. W. (2015). Metodologi Penelitian Bisnis dan Ekonomi. Yogyakarta: Pustaka Baru Press.

Wiagustini, N. L. P. (2010). Dasar-dasar manajemen keuangan. Denpasar: Udayana University Press.

Wijaya, B. I., \& Sedana, I. B. P. (2015). Pengaruh profitabilitas terhadap nilai perusahaan (kebijakan dividen dan kesempatan investasi sebagai variabel mediasi). E-Jurnal Manajemen, 4(12). 